\title{
Hungary's place on Eurasian rail land bridges and the eastern opening ${ }^{1}$
}

\author{
Z. ANDrew FARKAS²-Norbert PAP³ and PÉTER REMÉNYI ${ }^{2}$
}

\begin{abstract}
In the early $21^{\text {st }}$ century the global financial crisis changed the economic position of many states, including the EU, which is only slowly recovering, and the quickly emerging economies of Asia. Several factors in global transportation have driven countries to find alternative transport links and methods, including between Europe and Asia. Since 2010 government of Hungary has shifted the focus of Hungarian foreign policy towards "the East", which can be perceived as an interest-based real policy. The above factors and Hungary's landlocked position gave a renewed impetus to the so-called Eurasian land bridge issue, which intends to connect Central and Eastern Europe and East Asia on land. As the authors argue, after comparing foreign strategies of CEE countries, "eastern opening" of Hungary is not a unique move in the region, neither is the renewed interest in rail land bridges. However, after examining all the possible land routes towards East Asia, the authors agree with those who see these routes as unsustainable in the short run. On the other hand, the moves of Chinese private and state-owned companies in Southeast Europe and CEE, the "New Silk Road" concept of the Chinese diplomacy and expansion of the Suez Canal may foresee the establishment of micro land-bridges from SEE ports via Hungary towards Western Europe, significantly shortening the routes and avoiding congested northwestern ports. In this regard Hungary may play an important role on these alternative routes providing economic and geopolitical benefits.
\end{abstract}

Keywords: transportation, rail land bridges, foreign policy of Hungary, China, Southeast Europe,

\section{Introduction}

In 2010 Hungary saw the start of a significant restructuring in foreign policy. The main reasons behind it - among others - were the FIDESZ forming a new government that year, the global financial and economic crisis at the end of the previous decade, its consequences in Hungary and the specific economic and political reactions to it. The new foreign policy and economic relations brought a change in the orientation of Hungary to the East (Magyarország Külügyminisztériuma
2011). In addition to developments in diplomacy a number of concrete, practical steps are also needed, including the development of the physical transport infrastructure links between Hungary and the target countries of the "eastern opening." One of the links which are currently under-utilised for various reasons is continental rail corridors.

Significant transformations started in global communication and transport sectors at the end of the $20^{\text {th }}$ and early $21^{\text {st }}$ centuries, which have been fundamentally influencing sea and land transport possibilities. During

\footnotetext{
${ }^{1}$ Supported by the Think Visegrad Fellowship program of the V4 Think-Tank platform and the Publication and Research program of the Pallas Athéné Geopolitical Foundation within the framework of the research project Hungary and the $21^{\text {st }}$ century political world order.

${ }^{2}$ National Center for Transportation Management, Research and Development, Morgan State University, 1700 E. Cold Spring Lane, Center for Built Environment and Infrastructure Studies 327, Baltimore, MD 21251, E-mail: andrew.farkas@morgan.edu

${ }^{3}$ Department of Political Geography, Development and Regional Studies, Institute of Geography, Faculty of Sciences, University of Pécs, H-7624 Pécs, Ifjúság út 6. E-mails: pnorbert@gamma.ttk.pte.hu, remko@gamma. ttk.pte.hu
} 
the 1980s a new competitive order in the maritime industry and railway speed, efficiency and deregulation diverted some international container shipments to North American rail land bridges. While all-water transport from Asia to the United States East Coast continues to cost less than land bridge service, land bridges are typically faster (TALLEY, W. 2010). In addition if networks and rolling stock can be used more efficiently, the costs of railway transport over long distances can be reduced significantly (ILIE, E. 2010).

Land bridges operate in Canada and the U.S. and attempt to operate in Eurasia, but geography, policies, and infrastructure are very different between North America and Eurasia (VAssallo, J. and Fagan, M. 2007). One major innovation that facilitated land bridge development in North America is double-stacking of shipping containers on rail cars, which essentially doubles rail car capacity. No significant double-stacking occurs in Europe, because weight limits, bridge/tunnel heights and overhead electric wires are too low. North American rail densities (multiple tracks) and unified private ownership of rights-of-way and terminals are not likely to occur in Europe for quite some time, which makes it difficult for European railroads to increase freight market share (RodRIGUE, J.P. and Nоттевоом, T. 2010). In Asia insufficient investment in infrastructure and rolling stock; incompatible systems, gauges, and operations; and numerous border crossings add to the challenges of land bridges (RoDrigue, J-P. et al. 2013; IsLAm, D. et al. 2013).

Despite the challenges interest in Eurasian land bridges continues to grow. Almost all of the trade between China and Europe travels by sea and can take up to 40 days, resulting in high in-transit inventory costs (Vellenga, D. and Spens, K. 2006). Only 3.4 percent of Chinese exports reach the European Union (EU) by land (BAJOR, T. and ERDôsi, F. 2013). Many seaports in North Europe are highly congested, and Central and Eastern Europe (CEE), strategically located between Western Europe and China, could provide links, origins, and destinations for land bridges.
CEE countries have implemented national investment programs for railway infrastructure and rolling stock development to ensure connections to the Trans-European Railway Transport Network (TEN-T). Countries in Central Asia and in the Caucasus region have tried to invest similarly (ILIE, E. 2010).

China has invested in transport and distribution networks and logistical and assembly facilities throughout CEE. Its New Silk Road concept (presented in 2013), a network of various sea and land routes from China to the West, includes CEE as a potential gateway to Europe (Kaczmarski, M. 2015). Recently, China has agreed to finance upgrades to the Budapest-Belgrade railway line. It is also investing in Greek ports and national railway's land-side infrastructure as a way to open a gateway to European markets and reduce shipping times (KAKISSIS, J. 2014).

The authors' objectives are to summarise the transformation of Hungarian foreign policy since 2010 that has been in conjunction with changing global economic and transportation processes and describe and assess the opportunities for inland rail corridors linking Hungary with the Far East.

\section{Eastern opening in Hungary}

Hungary is a relatively small country with an open economy, where international trade plays a significant role in the creation of gross national product. In addition, from 2007 foreign trade has generated a surplus, and its volume has been growing steadily (except for 2009). In the foreign trade of Hungary, the EU Member States own a share of more than two-thirds of the total volume, while the share of the rest of the world is between 20-30 percent (KSH 2014).

The economic crisis in Hungary brought as in other countries - a decline in the volume of foreign trade, followed by, as a response, the intentional and unintentional transformation of the geographic dimensions of foreign trade. Because the European economic space was slowly emerging from the crisis, 
Hungary was looking for other directions toward seemingly more dynamic economies (ÉLtetó, A. and VöLgYi, K. 2013).

In 2011 the foreign policy strategy officially formulated the then-called "global opening" as a new foreign policy direction. The idea was that Hungarian foreign policy should not be confined to the mostly nearby traditional partners - in part because of more interdependent systems as a consequence of globalization, the rapidly increasing economic importance of some previously neglected geographical areas in the world economy, and should open towards less traditional partners (Magyarország Külügyminisztériuma, 2011).

According to the original idea, the East was only one direction of global opening; however, in practice it became the primary direction. Both the media attention and practical diplomatic activity were concentrated here. Key target countries were the eastern developed and developing states, China, Russia, India, Japan, South Korea, Vietnam, Kazakhstan, Georgia, the Gulf States and Turkey. The opening toward the East was born first of all as a classic, hypothetic foreign policy strategy, building on a perceived ancient, common national origin (based on the supposed Eastern or Asian origin of the Hungarians), where economic considerations were of secondary importance or did not appear as the responsibility of the apparatus for foreign affairs.

From the summer of 2012 (the change of the Minister of State in charge of the international relations of the Prime Minister's Office), and more prominently from the fall of 2014 (starting with the change of the leadership at the Ministry of Foreign Affairs), the global opening policy has been fully transformed to an eastern opening. Parallel to the above, the abstract and sophisticated diplomatic goals and means have been replaced by short-term economic interests, diplomatic goals have been subordinated to them, and instruments have been adjusted to accomplish them. This change has been received ambivalently both in Hungary and among its allies. The most common critique reproached Hungarian diplomacy for the transformation from a value-based approach to an interestbased approach. In this new direction, above all, China, Russia, other post-Soviet republics and some Gulf States were included in the priority group.

The reception of the Hungarian eastern opening policy in the target countries is controversial. In Russia, because of its involvement in the Eastern Ukrainian crisis (KARÁcsonyi, D. et al. 2014) and the intensified international isolation as a result, the Hungarian "opening" earned a positive reception, which has or had tangible economic results (South Stream, Paks II etc.). However, this positive reception may carry serious political risks for Hungary, since for Russia it is first of all a tool used to evade political isolation maintained by Hungary's allies. Thus, Hungary has found itself in between its "old" (allies) and "new" (Russia) friends. To meet the expectations of both is very difficult.

In Turkey the Hungarian aspirations were similarly well received. They are also linked to the strategic depth concept coined by Ahmet Davutoglu (Prime Minister of Turkey, then Minister of Foreign Affairs) and the neoOttomanism which aims to increase the influence of the Republic of Turkey in Southeastern Europe (FEKETE, J. 2014). The increased interest and openness from Hungary fit well into this concept. Turkey, however, is expected to show a significantly lesser "hard" (trade/investment) activity, but rather focuses shifts on "soft" diplomacy, strengthening cultural relations and renovating Ottoman heritage in Hungary, which has been manifested in many places in the form of tangible projects (Budapest, Szigetvár, Pécs) (PAP, N. 2014).

The attitude of other major target countries towards the opening efforts of Hungary is also ambivalent. The primary geopolitical objective of the Chinese pragmatism is to move towards a multi-polar world order in which the EU is interpreted as an important partner. In these efforts Hungary is necessarily perceived as an EU member and a CEE state, and not individually as a country of 10 million with a small and open economy. Furthermore, CEE (despite several multilat- 
eral meetings of China and CEE countries) plays a subordinate role in the China-EU relations. However, it is undeniable that from 2003 on Hungarian-Chinese relations are moving on an improving track (MATURA, T. 2012), Hungary traditionally describes itself as the center and gateway for Chinese interests in CEE. This gateway effect appears to be supported by both the significant Chinese diaspora in Hungary; the established formal and informal Chinese institutions, structures and networks; the growing volume of trade; and the planned Chinese investments and acquisitions in Hungary (Chinese schools and media, railway construction contracts, acquisition of BorsodChem, Bank of China, etc.). As for the other major powers in Asia (India, Japan), Hungary and its eastern opening policy is not significant to their scope of strategic directions and partners. These powers have other and fundamentally regional types of commitments.

\section{Eastern openings in Central Europe and the geopolitical constraints of Hungary}

After the economic crisis a turn towards the economies less affected by the crisis has been observed not only in Hungary. The other post-socialist CEE countries (among others) introduced "eastern openings" similar to that of Hungary's, directed towards the same regions as the ones in the Hungarian global opening strategy.

In Poland, the "eastern dimension" has always been one of the most important parts of foreign policy; relations with Russia and Polish minorities living in neighboring countries are important elements of it. Poland's openness to the east, its historical experiences and being in the neighborhood of great powers are all underpinning Poland being one of the main brokers of the Eastern Partnership within the EU (GÁcs, O. 2009). In addition the Tusk government (2007-2014) implemented a policy of rapprochement in both the German and Russian directions. Poland is in a key geostrategic location regarding inland rela- tions between Western Europe and the East, as much as (or even more than) Hungary, since the shortest route between Moscow and Berlin (which has repeatedly caused disasters in Polish history) leads through Warsaw.

In 2011 Slovakia - similarly to Hungary - adopted a new strategy of foreign affairs with a clear focus on "global" opening (in the directions of China, India, South Korea, Japan, Indonesia, Mexico, Brazil, Argentina) (Ministry of Foreign Affairs of Slovakia without year). Also, the Czech Republic in 2011 adopted a new concept of foreign policy, which, along with the EU and NATO obligations, envisaged the strengthening of relations with Russia (Ministry of Foreign Affairs of the Czech Republic 2010). The Romanian strategy of foreign affairs (adopted in 2009 for ten years) aligns its efforts in the Caspian and Black Sea region to the EU's strategy on Central Asia. However, one can observe here, due to the Romanian inhabited regions of Moldova and Ukraine, a kind of detachment as well.

A common feature of CEE "eastern openings" is that instead of accepting a European economy in crisis, they have turned attention to other directions to find trade partners and investors. Apparently, they find more or less the same target countries and thereby a sense of rivalry for eastern markets and investors. A further common feature is that the wide social support of the new foreign policy directions can be questioned. While in some of the Slavic countries (e.g. Slovakia) there is a kind of pan-Slavic sense of common interests regarding the relations with Russia (MARUsiak, J. 2013), Hungary is experiencing a renaissance in referencing its East Asian roots when improving relations with Asian states. However, in reality these ideas are rarely suitable to influence decisions of real economic or political benefit.

For Hungary - which may be true for Slovakia and the Czech Republic as well - the new inland dimensions of eastern relations have an additional significance which can be explained by the country's land-locked position. Hungary's international trade with 
the Far East uses today the European transit ports. They are either on the North Sea or the North Adriatic or to a lesser extent, can be found on the Black Sea. Creating and operating a direct, active connection of inland routes with the Far East is, therefore, not only of economic, but also of geopolitical/geo-strategic significance (PAP, N. 1999; PAP, N. et al. 2012).

\section{Maritime transport}

According to Rodrigue and Notteboom North American and Eurasian land bridges are being challenged by increasing economies of scale in maritime shipping. Over the past 20 years, the number and average size of container ships has increased significantly, and fleet capacity is expected to expand further (Rodrigue, J.-P. and Notтeвoom, T. 2012). Rising maritime fuel prices provided the incentive for building much larger ships to reduce fuel costs per unit. The impact of this expansion in capacity will be a reduction in shipping rates in general, until small ship capacity is reduced (GARRATT, M. and Teodoro, A. 2013).

The growth in number and size of container ships has encountered the physical constraints of the Panama Canal. The maximum capacity of ships that can currently transit the canal is about 5,000 TEUs (Twenty Foot Equivalent Unit containers) and the size class ranging from 4,000 to 5,000 TEUs is designated as "Panamax". Ships have been built to realise economies of scale on routes that did not include the Panama Canal - in particular, the East Asia-Europe and East Asia-U.S. West Coast routes. The potential economic advantages of even larger container ships (Suezmax) coupled with U.S. rail land bridge operations have been major factors behind a Panama Canal expansion program (Panama Canal Expansion Study 2013).

Once the world economic recovery and Panama Canal expansion are complete, larger container ships and supply chains may impose competitive challenges on long distance rail service, but there are divergent opinions on the extent of competition. Global freight distribution, trade flows, shipping network configurations and transshipment, strategies of maritime shipping companies and terminal operators, and supply chain management have become so complex and interrelated that it is unclear what the canal expansion will ultimately do to transport cost structures and trade routes (Rodrigue, J.-P. and Nоттевоом, T. 2012).

The maximum-sized ship that could transit through the expanded Panama Canal will have a capacity of up to 13,000 TEUs or more (Post-Panamax). A major U.S. Department of Transportation study found that although only 12 to 14 additional vessels per day can be accommodated in the new canal lock system, the increased size of vessels will result in doubling Panama Canal throughput from 300 million tons to 600 million tons (Panama Canal Expansion Study 2013).

After Panama Canal expansion, there may be opportunity for more "round-the-world" liner services. Some global carriers may deploy Post-Panamax ships eastbound from East Asia through the Panama Canal to the U.S. East Coast, to a few Mediterranean ports, through the Suez Canal and then across the Indian Ocean back to East Asia (Panama Canal Expansion Study 2013). Such services may also run westbound from East Asia to the Suez Canal and one or two Mediterranean transshipment ports, then across the Atlantic to the U.S. East Coast, and return to Asia via the Panama Canal.

The Suez Canal in any case already dominates container ship traffic between East Asia and Europe and has abundant capacity to accommodate Post-Panamax ships. Yet, as container ship sizes grow above the 13,000 TEU limit of an expanded Panama Canal and as economic growth in Southeast Asia leads to more container cargo along a westbound route, the Suez Canal will likely become even more important (Panama Canal Expansion Study 2013).

Two factors besides transport costs are generally considered to be the prime determinants of how and which way goods are 
moved: reliability and transit time. Transit time is important in determining how goods move, because high-value, "just-in-time" cargos typically demand faster shipping, while low-value cargos do not. An important consideration in defining costs is load imbalances by direction. For example, there may be a huge imbalance in direction for shipping cargo between two locations. Staging of vehicles at route origins and destinations is more problematic. Excess capacity in one direction must be compensated by the cargo shipped in the other direction. Given all the variables in the geography and economics of maritime and rail transport, could Eurasian land bridges succeed over the long-run?

\section{Eurasian land bridge issues}

One rail corridor often comes to the fore when Eurasian land bridges are discussed. While the Trans-Siberian Railroad has provided rail service between Vladivostok and Moscow since 1916, the development of a true Eurasian land bridge began in the late $20^{\text {th }}$ century. Geopolitical considerations and the collapse of the Soviet Union in the early 1990s created instability within Russia and its former republics, as well as a lack of investment in and maintenance of facilities, so the corridor as an international trade route was essentially abandoned (RodRIgue, J-P. et al. 2013). The Trans-Siberian in the 1980s carried over 11 percent of container traffic between Asia and Europe, but by the early 2000s, it carried only 1-2 percent (Vellenga, D. and SPENs, K. 2006).

The beginning of the $21^{\text {st }}$ century has brought renewed interest in the TransSiberian Railroad, especially because of the booming Asian trade with Europe and the increasing pressure to ship containerised freight in a time sensitive manner over long distances (Rodrigue, J-P. et al. 2013). The „Beijing-Hamburg Container Express" was initiated and tested in 2008 to avoid congestion at Chinese coastal ports. The 10,000 km service can take 15 days to link the Chinese capital to the German port city, traversing Mongolia, the Russian Federation, Belarus and Poland, a duration half that of the maritime trip of 30 days (Rodrigue, J-P. et al. 2013). A variation of this service, the "Antwerp Chongqing Rail Freight Service," tested at the end of 2011, takes 20 to 25 days. Yet, service as of June 2014 is from East to West only with no goods shipped West to East, so profitability is doubtful (Rail offers... 2014).

As in previous years, there are continuing impediments to the Trans-Siberian Railroad: excessive bureaucracy, government inefficiency and corruption; insufficient investment in transport systems; limited rolling stock; and poor customer service (Vellenga, D. and Spens, K. 2006; Bajor, T. and Erdôsi, F. 2013). In addition, several countries on a Eurasian route, including Russia, apply discriminatory fees to international rail shipments.

IsLAM, D. et al. (2013) compared three often discussed Eurasian land bridge alternatives: 1) Trans-Siberian Corridor with various alternative routes, 2) Central Corridor and 3) TRACECA Corridor with two alternative routes (Figure 1). Each corridor could have branch lines that originate or terminate in CEE, but the technical capabilities vary significantly (Table 1). The authors found that the Trans-Siberian has shortages in container and handling capacity. The central corridor through Kazakhstan, Romania and Hungary has differing electrical systems, obsolete roll-

Table 1. Technical capabilities of the three routes

\begin{tabular}{l|c|c|c|c}
\hline \multicolumn{1}{c|}{ Corridor, route } & $\begin{array}{c}\text { Distance } \\
\mathrm{km}\end{array}$ & $\begin{array}{c}\text { Double tracked } \\
\text { and electrified }\end{array}$ & $\begin{array}{c}\text { Average } \\
\text { speed km/h }\end{array}$ & $\begin{array}{c}\text { Loco } \\
\text { changes }\end{array}$ \\
\hline Trans-Siberian corridor with 3 routes & 9,288 & Most part & 76 & 3 \\
Central corridor & 3,930 & One-eighth & 40 & 3 \\
TRACECA corridor with 2 routes & 5,000 & Less than half part & 40 & 2 or 4 \\
\hline
\end{tabular}

Source: IsLAM, D. et al. 2013. 


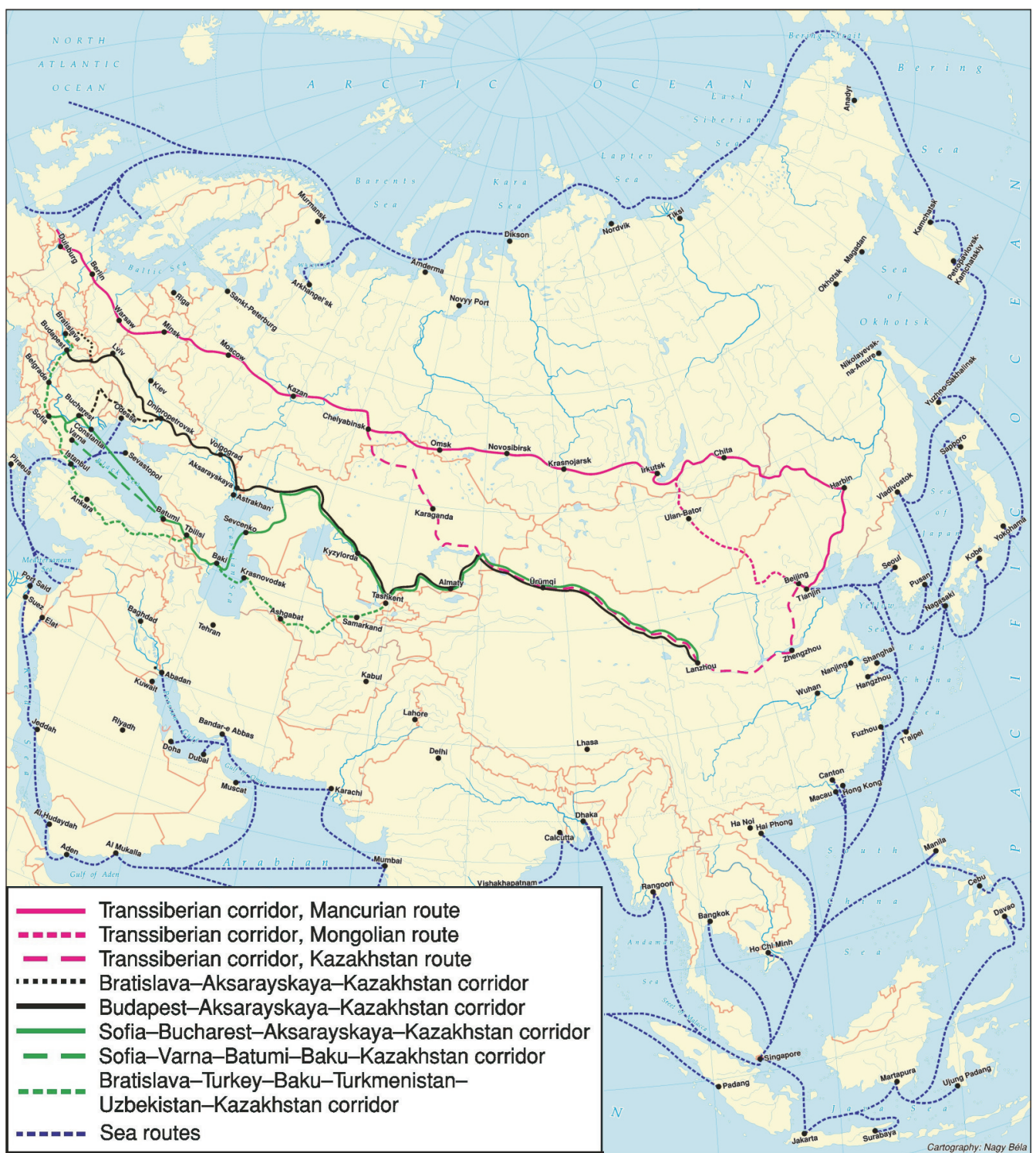

Fig. 1. Trans-Siberian, Central and TRACECA corridors with railway routes between China and Europe and major maritime routes. Source: Islam, D. et al. 2013. Cartography: NAGY, B.

ing stock, and insufficient cargo handling equipment. The TRACECA corridor does not yet exist as an integrated system and has the least reliable transit time.

IsLAm, D. et al. (2013) conclude that despite the difficulties, the Trans-Siberian Corridor offers the most advantages to compete with maritime service. The second best route is the Central Corridor and TRACECA has the least potential. BAJOR, T. and ERDósI, F. (2013) seem to agree with this ranking. Yet, all three corridors are characterised by gauge changes, "... unreliable transit time, higher transport cost, loss, damage, and theft of cargo..." (IsLAM, 
D. et al. 2013). Another study concluded that new rail lines for international freight traffic through Ukraine or Russia "...would be very risky ventures, and doubts should be raised as to whether those services could ever be economically viable without massive subsidies" (Combined Transport Group 2010). The recent geopolitical conflict in Ukraine calls into question for the near future reliance on a Trans-Siberian Corridor.

\section{Hungary's railways}

Hungary has been innovative in seeking new management and ownership models for international rail service. It has participated successfully in the establishment of private sector rail service through the EU-sponsored RETRACK demonstration project, consisting of viable service between Hungary and the Benelux countries (van Rooijen, T. et al. 2012). The demonstration focused on bulk freight, such as grain and chemicals, not intermodal containers, but lessons learned can be applied to other product shipments.

All main railway lines in Hungary have sufficient capacity now and in the future. The highest capacity use rates are 60 to 70 percent, while most are 30 to 50 percent (Combined Transport Group 2010). Hungary has sufficiently high height limits to allow high cube containers and semi-trailers on flat cars (but not double stack). However, most of Hungary's railways have train axle load limits of up to 20 tons, which limits shipping of cargos heavier than maritime containers. Also, there are several sections with speed restrictions resulting from lack of rail maintenance (Combined Transport Group 2010).

The Hungarian government has focused on expansion of intermodal transport and connectivity in an effort to improve its railways. It has provided funding for construction of intermodal terminals, invested in logistics centers' accessibility, and subsidised transport services. Most intermodal container traffic in Hungary will continue to be centered on Budapest, but other locations could play a bigger role, as the geography of traffic flows changes (Combined Transport Group 2010).

New transport and logistics infrastructure can transform economic geography and initiate development, especially where intermodal transfers (break bulk) occur and particularly in less developed locations. Such is the case historically at the intermodal terminal on the Ukraine/Hungarian border at Záhony, where rail gauges change, and terminal, trans-shipment and warehousing activities occur.

The Russians have recently suggested building a rail line with their wider gauge all the way to Vienna to facilitate a Eurasian link. Such a rail line could bypass Hungary entirely, if built through Slovakia, for example, and BAJor, T. and Erdósi, F. (2013) express concern that such an alignment would mean no economic benefit to Hungary. Even if a wide-gauge line were built through Hungary, it would pass Russian freight shipments through the country with perhaps no intermodal transfer and, thus, create little economic benefit beyond transit fees, once construction is complete. Such a proposal also begs questions of who would build it and whether nations crossed by it would approve in light of geopolitical and transport economics concerns.

It is expected that intermodal container traffic will expand greatly in Hungary by 2020, generated by East Asia and Europe trade and freight transport through the Balkans (Combined Transport Group 2010; Ruppert, L. 2011). A significant part of this container traffic could come through the Suez Canal to the ports of the Mediterranean, Adriatic and the Black Sea to be unloaded (Ruppert, L. 2011). Hungary (and Budapest in particular) is well endowed with intermodal service providers and its central location within trans-European transport corridors, serving freight trips to the west, northeast and southeast (Combined Transport Group 2010) (Table 2). Yet, Hungary has concerns over the uncertainty regarding the port or combination of ports that would be of most benefit. Hungarian routes can be by-passed 
Table 2. Selected ports' traffic and transport links to Budapest in 2011

\begin{tabular}{|c|c|c|c|c|c|c|}
\hline \multirow[t]{2}{*}{ Port } & Capacity & $\begin{array}{c}\text { Capacity } \\
\text { utilisation }\end{array}$ & \multirow{2}{*}{$\begin{array}{c}\text { Number of con- } \\
\text { tainers, } 1000 \text { TEU } \\
\text { per year }\end{array}$} & \multirow{2}{*}{$\begin{array}{c}\text { Distance from } \\
\text { Budapest by rail, } \\
\text { km }\end{array}$} & \multirow{2}{*}{$\begin{array}{c}\text { Rate of } \\
\text { double-tracked } \\
\text { railways, \% }\end{array}$} & \multirow{2}{*}{$\begin{array}{l}\text { Rate of } \\
\text { express } \\
\text { roads, \% }\end{array}$} \\
\hline & \multicolumn{2}{|c|}{ million tons per year } & & & & \\
\hline Trieste & 65 & 52 & 2,650 & 680 & 70 & 100 \\
\hline Koper & 22 & 15 & 500 & 650 & 69 & 100 \\
\hline Rijeka & 25 & 10 & 140 & 595 & 17 & 100 \\
\hline Thessaloniki & 28 & 16 & 273 & 1,104 & 11 & 95 \\
\hline Constanta & 68 & 46 & 670 & 1,126 & 100 & 36 \\
\hline
\end{tabular}

Source: Erdősi, F. 2013.

and transport infrastructure in the Balkans is currently inadequate (DTZ Research 2008; RUPPERT, L. 2011).

\section{Southeastern Europe transport links to Hungary}

Balkan railways have been fragmented, have suffered from disinvestment and are competing with refurbished roads (RUPPERT, L. 2011). Disjointed and short lines, many borders, poor infrastructure, and competition with roads are anathema to railways. Yet, as has been noted, Greece is considered as an East Asian gateway to European markets (DTZ Research 2008; KAKIssis, J. 2014). Shipments through Piraeus and CEE can save between four and ten days compared to all water shipments to northern European ports (Palaiologos, Y. 2015). China Ocean Shipping Company (COSCO) has signed a 4.3 billion EUR agreement to manage the Port of Piraeus for 35 years (JING, F. 2011). COSCO has decided to spend another 620 million euros on improvements at the port and on construction of a new pier. These investments, management and excellent access to CEE have brought more business to the port (Alkis, J. and PApachristou, Y. 2013).

A route that could compete with other Balkan corridors to Hungary or become an integral part would be a new high-speed rail line from Rijeka to Zagreb, including an upgrade of the current line from Zagreb to Botovo on the Hungarian border (ERDósI, F. 2013; Gebrüder Weiss... 2014). Rijeka is a major maritime container port on the Adriatic that can accommodate deep draft ships. However, the current rail connection in Croatia is old, slow and low capacity, so much trucking of containers occurs. The Croatian Government is planning to seek private investment and concessionaires for a railway tender estimated to cost 5 billion EUR (Gebrüder Weiss... 2014). China has expressed to the Croatian government some interest in the port and its railway to Zagreb as an additional gateway to Europe (News staff 2012; YuHuAN, L. 2013).

Slovenia and Romania have also attempted to attract foreign investments to improve and expand the ports of Koper and Constanta, respectively (JING, F. 2011). The port complex of Trieste (Italy) and Koper is already served by double tracked railways and thus has an advantage over Rijeka and good prospects for future container traffic. Turkish firms have developed and operate a roll-on roll-off terminal at the port of Trieste for ships hauling vehicles made in Turkey. The vehicles would then be shipped by train and could travel through Hungary. Constanta in Romania also has a major container terminal. China has established a 6.5 billion USD financial arrangement with Romania, which could result in substantial investments in infrastructure.

Because of the EU's East-West transport investment focus in the past and the Euro financial crisis in 2008 and 2009, a resulting investment vacuum and Chinese budget surpluses encouraged China to make strategic transport investments in Greece and the Balkans (Matura, T. 2014). China has indicated through its investments that it wishes to avoid the congested North Sea megaports 
and not rely on the Trans-Siberian Railway partly because of concerns over the geopolitics of Ukraine. As noted, a southern railway corridor in Central Asia, while of interest to China, has even more challenges.

The Chinese have different investment objectives from the EU and expect that there will be explicit short and long-term returns to their loans and investments. In addition, Chinese transport infrastructure investments promote Chinese consulting and construction firms and rail manufacturing exports and increase international market shares for those sectors of the economy (KaczmarsKi, M. 2015).

\section{Conclusions}

The challenges to building and operating full rail land bridges across Eurasia are enormous, logistically, economically and politically. Land bridges are being challenged by increasing economies of scale in maritime shipping. The physical and operational constraints in Eurasia, including no double-stacking of containers, are major obstacles to land bridge efficiency. Full Eurasian land bridges may play a minor role for unique charter shipments, but significant, regularly scheduled common carriage is currently unsustainable.

The land bridge corridor which appears to have the most potential for the foreseeable future is the Trans-Siberian Railroad with connections to China. In addition to the huge economic and logistical challenges, corruption and the geopolitics of Ukraine interfere with this corridor's potential. The current sanctions on Russia may preclude initiatives for more container traffic on the Trans-Siberian to the West.

Westbound shipping rates should remain very competitive with alternative overland modes and routes because of overcapacity of large container ships and abundant capacity in the Suez Canal. Expansion of the Panama Canal will create complementarities with the Suez Canal for East Asia originated round-theworld service and the Suez Canal will continue to dominate East Asian traffic to Europe.
If container ships continue to increase in size and Suez Canal capacity remains sufficient, then there would be opportunities for more intermodal traffic from Greek, Black Sea, and Adriatic seaports through the Balkans and to the rest of Europe. Indeed, one could expect that more Suez Canal traffic would create opportunities for Eurasian micro land bridges from these seaports to locations within CEE, as CEE grows economically.

China seems to have made its intentions known by investing in Balkan rail connections and Greek ports and railways, but more railways improvements are required in the southern Balkans. Maritime container shipping through the ports of Constanta, Koper, and Rijeka (Croatia) could be alternatives to shipments from Piraeus and Thessaloniki, but significant rail enhancements from all of the ports are necessary.

It is obvious that changes in the foreign policy of a state of the size of Hungary are insufficient to modify transport routes determined by global economic considerations. Hungary's 'eastern opening' and Eurasian rail land bridges fall into this 'rule' too, no significant near future increase in the volume of the goods transported by them are expected. However, leaving the possibility open to operate such links, which may end in Hungary, bears geostrategic significance.

On the other hand, with the Chinese global economic expansion and the various plans included in the 'New Silk Road' concept may increase the significance of Hungary on the Western Europe-East Asia trade, including the increase of the volume of rail transport, since Hungary is also an important land transportation hub on the routes from the Balkans to Western Europe. As the various Chinese investments in the Balkans (port of Piraeus, Budapest-Belgrade high speed railway development, overall upgrade of Serbian railway infrastructure etc.) start to take shape and form an interconnected network Hungary would find itself in a similar position as with the Eurasian rail land bridge: becoming an important transit/logistic hub on the East Asia-Western Europe trade. 
Classic ports-based transport development models suggest that when inland transport networks develop, some ports become gateways and thrive, while others languish. While it is beyond the predictive powers of Hungary to forecast which Balkan ports will ultimately attract the needed high speed rail connections and develop the most container traffic (besides Piraeus, China is interested in Greek ports Thessaloniki and Igoumenitsa, Montenegrin port Bar and other Adriatic ports as well).

Hungary and the other CEE countries and Balkan neighbours should coordinate their "eastern openings" and focus on north-south rail links, distributive road networks and intermodal facilities, in order to utilise and benefit from the supposedly increased transit flows in the region.

Hungary's role, furthermore, should be to create an economic and political environment to facilitate investments in North-South land transport infrastructure and networks to raise weight limits and speed. Also, Hungary should monitor transport developments in her neighbours and coordinate policies with them to attract additional EU and Chinese intermodal transport investment. An important task for Hungary is to cooperate with its southern neighbours in the facilitation of border crossings, its physical and political environment, which may be a challenge due to the recent migration flows using very similar routes and causing political dissent among states in the region. An elaborating a coordinated and joint 'eastern opening' of the relevant CEE and SEE states would also be welcomed since it would give the small European states a somewhat larger lobby power, cost-effective ways of developments and more coherent planning.Currently the Chinese planned developments are in line with the aims of the EU, since majority of them coincide with the EU's TEN corridors (first of all Corridor 10). Should it change, Hungary would have other important tasks: to mediate between EU's and China's interests, and try to be a beneficiary, a link between the EU and China.

\section{REFERENCES}

Alkis, J. and Papachristou, Y. 2013. Greek ports: Market transparency and future prospects. Academia. edu. http://www.academia.edu/4420077/Greek_ ports_market_transparency_and_future_prospects. Retrieved 13 October 2014.

BAJor, T. and ErdősI, F. 2013. Alternative routes between the Far East and Europe (With special regard to the foreign trade of Hungary). Discussion Papers 92. Pécs, Institute for Regional Studies, Hungarian Academy of Sciences, $56 \mathrm{p}$.

Combined Transport Group 2010. DIOMIS: Evolution of Intermodal Rail/road Traffic in Central and Eastern European Countries by 2020, Hungary. Paris, International Union of Railways, $105 \mathrm{p}$.

DTZ Research 2008. The rise of the Balkans: European logistics report 2008. 24 p. http://www.balkans.com/relevant/c04e7-DTZ_The_Rise_of_the_Balkans_08.pdf. Retrieved 15 July 2014.

Éltető, A. and Völgyı, K. 2013. „Keleti nyitás” a számok tükrében - külkereskedelem Ázsiával (Statistics of „Eastern opening” - foreign trade with Asia). Külgazdaság 57. (7-8): 67-104.

Erdősı, F. 2013. A közeledő Távol-Kelet: A transzeurázsiai közlekedési kapcsolatok jelene és jövője. (Far East in approach. The presence and future of the TransEurasian transport connections). Pécs, IDResearch Kft.-Publikon Kiadó, 282 p.

FeKETE, J. 2014. Törökország külpolitikája és kulturális jelenléte a Balkánon (Foreign policy and cultural presence of Turkey in the Balkans). In Állam-és nemzetépités a Nyugat-Balkánon. Ed.: RemÉNYI, P. Pécs, IDResearch Kft.-Publikon Kiadó, 165-184.

GÁcs, O. 2009. Az Európai Unió keleti politikája lengyel szemmel (Eastern policy of the European Union in Polish view). Nemzet és Biztonság 2. (10): 24-36.

Garratt, M. and Teodoro, A. 2013. The impact of increasing container ship capacity: Wider implications. Presentation at Global Liner Shipping Conference, London. 18-19 April, 2013.

Gebrüder Weiss Transport and Logistics 2014. Croatia: Zagreb-Rijeka railway project in pipeline. http://www. gw-world.com/en/ostnews-ausgaben/ostnews/single/ ostnews-nr-93/croatia-zagreb-rijeka-railway-projectin-the-pipeline/ Retrieved 8 September 2014.

ILIE, E. 2010. The railway infrastructure enhances economic development Railway PRO. http://www.railwaypro.com/wp/?p=758. Retrieved 14 May 2014.

Islam, D., Zunder, T., Jackson, R., Nesterova, N. and Burgess, A. 2013. The potential of alternative rail freight transport corridors between Central Europe and China. Transport Problems / Problemy Transportu 8. (4): 45-57.

JING, F. 2011. Black Sea ports offer much promise. China Daily. http://www.chinadaily.com.cn/china/ 2011weneurope/2011-06/25/content_12774677.htm. Retrieved 18 September 2014. 
Kaczmarski, M. 2015. The New Silk Road: a versatile instrument in China's policy. OSW Commentary $161.9 \mathrm{p}$.

KAKIssis, J. 2014. China forges stronger economic ties with Greece. National Public Radio. http://www.npr. org/2014/06/19/323510603/china-forges-strongereconomic-ties-with-greece. Retrieved 19 June 2014.

Karácsonyi, D., Kocsis, K., Kovály, K., Molnár, J. and Póti, L. 2014. East-West dichotomy and political conflict in Ukraine - Was Huntington right? Hungarian Geographical Bulletin 63. (2): 99-134.

KSH 2014 Statisztikai Tükör 20. Budapest, Central Statistical Office, 3 p.

Magyarország Külügyminisztériuma 2011. Magyar külpolitikai az uniós elnökség után (Hungarian foreign policy after the Hungarian EU presidence). Budapest, Ministry of Foreign Affairs, $54 \mathrm{p}$.

MARusiaK, J. 2013. Slovakia's Eastern policy - from the Trojan horse of Russia to "Eastern multivectoralism". International Issues \& Slovak Foreign Policy Affairs 22. (1-2): 42-70.

Matura, T. 2012. A magyar-kínai kapcsolatok elmúlt két éve (Last two years of the Hungarian-Chinese connections). Külügyi Szemle 2. 9-23.

Matura, T. 2014. A personal interview on 30 September 2014. Budapest.

Ministry of Foreign Affairs of Slovakia (without year): Orientation of the Foreign Policy of the Slovak Republic in 2010. Bratislava. http://www.foreign.gov.sk/App/ wcm/media.nsf/vw_ByID/ID_78DED0BDDD8B3A 35C1257706002D8E9C_EN/\$File/Zameranie_2010_ fin_EN.pdf. Retreived 30 June 2015.

Ministry of Foreign Affairs of the Czech Republic 2011. Conceptual Basis of the Foreign Policy of the Czech Republic. Unofficial English translation. http://www. mzv.cz/file/ 681350/koncepce_zahranicni_politiky_2011_en.pdf. Retreived 30 June 2015.

News staff 2012. COSCO eyes investment in north Croatian port of Rijeka. Port Technology International. http://www.porttechnology.org/news/cosco_eyes_ investment_in_north_croatian_port_of_rijeka/\#. VB1_kfl_tDB. Retrieved 17 September 2014.

Palaiologos, Y. 2015. China's new silk road might save Greece. Politico. www.politico.eu/article/chinas-new-silk-road-might-save-greece/. Retrieved 1 May 2015.

Panama Canal Expansion Study 2013. Phase I Report: Developments in trade and national and global economies. Washington DC, Maritime Administration, US Department of Transportation.

PAP, N. (ed.) 2014. Szülejmán szultán emlékezete Szigetváron: Kanuni Sultan Süleyman'm Sigetvar'daki hatirasi. Mediterrán és Balkán Fórum, Vol. 8. Special issue. Pécs, PTE TTK Kelet-Mediterrán és Balkán Tanulmányok Központja, 135 p.
PAP, N. 1999. Korridorok Köztes-Európában (Corridors in Intermediate Europe). Földrajzi Közlemények 123. (3-4): 180-190

PAP, N., Reményi, P. and Végh, A. 2012. Corridors in the Western Balkans and the Hungarian exit to the sea. Revista Romana de Geografie Politica 14. (2): 176-188.

Rail offers alternative for conditioned transport to Far East 2014. Hellenic Shipping News Worldwide: Online Daily Newspaper on Hellenic and International Shipping. http://www.hellenicshippingnews.com/ rail-offers-alternative-for-conditioned-transportto-far-east/. Retrieved 28 July 2014.

Rodrigue, J.-P. and Notтевоом, T. 2010. Comparative North American and European gateway logistics: The regionalism of freight distribution. Journal of Transport Geography 18. (4): 497-507.

Rodrigue, J.-P. and Notteboom, T. 2012. The Panama Canal expansion: Business as usual or game-changer? Port Technology International 53.10-12. http://people.hofstra.edu/jean-paul_rodrigue/downloads/ PT51-10_3.pdf. Retrieved 12 May 2014.

Rodrigue, J-P., Comtois, C. and Slack, B. 2013. The Geography of Transport Systems. $3^{\text {rd }}$ edition, New York, Routledge.

Ruppert, L. 2011. The impact of the Southeast-Oriented transport of the EU on Hungary. Budapest, Europa Institute. 129-135. http://www.europainstitut. hu/index.php/17-begegnungen/251-begegnungen28rupert. Retrieved 3 July 2014.

TAlley, W. 2010. Shipping. In Intermodal Transportation: Moving Freight in a Global Economy. Eds.: Hoel, L., Giuliano, G. and Meyer, M. Washington, DC, Eno Transportation Foundation, 133-159.

van Rooijen, T., van de Lande, P., Zhang, M., Mortimer, Ph., Jackson, R., Islam, D., Vleugel, J. and Eidhammer, O. (Eds.) 2012. The RETRACK Project-Reorganization of Transport Networks. Delft, TNO Van Mourik Broekmanweg. https://www.tno.nl/downloads /retrack_final_report.pdf. Retrieved 9 September 2014.

VASSALLO, J. and FAGAN, M. 2007. Nature or nurture: Why do railroads carry greater freight share in the United States than in Europe? Transportation 34. (2): 177-193.

Vellenga, D. and Spens, K. 2006. Expansion of container traffic from Asia to the EU via the use of intermodal landbridge services - questions and issues. In Contemporary Research Issues in International Railway Logistics. Tutkimusraportti Research Report 171. Ed.: Himora, O-P. Lappeenrannan teknillinen yliopisto, tuotantotalouden osasto. 111-118.

Yuhuan, L. 2013. Croatia deepens ties with China. Global Times. http://www.globaltimes.cn/ content/820708. shtml. Retrieved 17 September 2014. 